\title{
Students' Readiness to Learn in the A Five-Day School Policy in the Public Senior High School of Yogyakarta
}

\author{
Nuniek Rahmatika, Suyatno* \\ Department of Education Management, Universitas Ahmad Dahlan, Indonesia
}

Received April 8, 2020; Revised July 20, 2020; Accepted August 10, 2020

\section{Cite This Paper in the following Citation Styles}

(a): [1] Nuniek Rahmatika, Suyatno, "Students' Readiness to Learn in the A Five-Day School Policy in the Public Senior High School of Yogyakarta," Universal Journal of Educational Research, Vol. 8, No. 11, pp. 5005-5014, 2020. DOI: 10.13189/ujer.2020.081101.

(b): Nuniek Rahmatika, Suyatno (2020). Students' Readiness to Learn in the A Five-Day School Policy in the Public Senior High School of Yogyakarta. Universal Journal of Educational Research, 8(11), 5005-5014. DOI: 10.13189/ujer.2020.081101.

Copyright $(2020$ by authors, all rights reserved. Authors agree that this article remains permanently open access under the terms of the Creative Commons Attribution License 4.0 International License

\begin{abstract}
The Indonesian government has implemented a five-day school policy, which resulted in the extension of the students' learning period at school. Previously, students learned at school from 07.00 to 13.30 . Now, students stay longer at school, which is until 15.30 . From the perspective of the students' readiness, the policy is interesting to study. Psychologically, students have a short span of learning concentration. The research aims to analyze the students' learning readiness in the implementation of a five-day school policy. The study belongs to the quantitative type by using a survey to collect the data. The samples are 145 students of senior high schools in Yogyakarta, Indonesia $(38.6 \%$ male, $61.4 \%$ female). The instrument is a questionnaire distributed through Google form, and the data obtained from the questionnaire were analyzed using descriptive statistics and product moment. From the results, the school must establish a policy to improve the students' readiness, particularly the students' attention. The policies can be adopted in the curriculum management and fun learning activities. An advanced study is necessary by employing more various samples, involving schools from several demographics, both private and public, either in the city or in the village. It is to gain representative aspirations for the government in evaluating the five-day school policy.
\end{abstract}

Keywords Learning Readiness, Attention Span, Learning Motivation, Readiness Development, Five-Day School Policy

\section{Introduction}

The Indonesian government has established a five-day school policy. As a consequence, students stay longer at school. Previously, they learn from 07.00 until 13.30. Now, they have to learn until 15.30 (Triyono, 2018). The change requires some adjustments in several aspects, such as curriculum modification, classroom management, facilities, infrastructure, and learning methods, to prevent students' boredom. The policy is implemented in accordance with the operational standards of the Civil Servants (ASN-Aparatur Sipil Negara), Directorate-General for Teachers and Educational Staffs of the Ministry of Education and Culture, stating that the policy is related to the Government Regulation Number 19 of 2005 regarding the working hours for teachers and headmasters. In the regulation, teachers and headmasters work up to forty hours per week with a 30-minute break in a day. In other words, they work for 37.5 hours a week.

The main goal of the five-day school program is to improve the quality of education through effective and efficient time management at school (Anifah, 2016). Besides, high demand and people's mobility require a new concept in education, which results in the five-day school program. People with high mobility will work from morning until evening. They may work overtime. Consequently, they cannot help their children learn at home (Ningrum, 2019).

The policy makes students stay longer at school, leading them to exhaustion and boredom (Suharno, 2018). However, the Special Region of Yogyakarta, which is 
known as the city of education, shows a positive response to the policy. Many schools support the program, especially at a senior high level. All senior highs in Yogyakarta have applied for a five-day school program, following the policy established by the local government. Several experts have their perspective on the policy. Some of them respond positively, some of them negatively. Triyono (2018) stated that the implementation has a terrible impact on the students' psychological condition, in that it may cause exhaustion. The policy requires the students to stay longer at school, leading them to feel tired and bored. The gaps in the implementation can influence the students' psychological and academic aspects (Triyono, 2018). A more extended learning period may cause anxiety and frustration (Yuan, 2012). The pressure that occurs in the learning process will lead to academic stress (Mortaki, 2012). Academic stress is caused by the academic load in the learning process or by other things that are related to learning activities (Mortaki, 2012). Furthermore, a full-day school may cause a less optimal learning process because it forces students to study harder within a longer period (Ikhwandhia, 2016).

Previous studies show that research on students' learning readiness in facing full-day school has caused several problems in the students' side. However, the studies have not mentioned the main factor related to their readiness, nor about the motivation to encourage students to follow the new program. Indeed, learning motivation has been the subject of many studies (Karabuk, 2015). It is known that motivation is one of the main factors that influence students' success. In addition, Lim (2004) stated that motivation is a critical element in learning readiness. It can be seen in the accomplishment of the tasks, in that students are punctual and highly motivated, as well as capable of overcoming the problems during the learning process (Bakar, 2014). Similar to motivation and expectation, all learning components can influence the learning outcome (Horwitz, 1985).

Based on the problems, the research is to answer the questions formulated as follows.

1. How ready are the students in terms of attention related to the implementation of five-day school policy in the public senior high schools in Yogyakarta?

2. How ready are the students in terms of motivation related to the implementation of five-day school policy in the public senior high schools in Yogyakarta?

3. How ready are the students in terms of developing the readiness in the implementation of five-day school policy in the public senior high schools in Yogyakarta?

\section{Literature Review}

\section{Definition of Students' Learning Readiness}

Learning readiness is an overall condition promoting the students' preparedness in responding to a particular situation. Slameto (2010) explained that learning readiness is the whole condition of an individual that makes him ready to give responses or answer in a specific way in a certain situation. The state refers to the physical and psychological aspects. Therefore, to achieve maximum readiness, an individual needs to have good physic and mentality to help them follow the learning process. Students' readiness can determine the quality of the learning process and the learning achievement.

Murray and Harrison (Lambert, 2003) suggested that learning readiness includes non-cognitive areas, such as disposition, behavioral skills, social skills, obedience, communicative skills, and needs management. Students' experience at school can affect their reaction in solving the problem. Previous studies have shown that children's characteristics influence their readiness and academic performance. Besides, teachers (Murraya \& Harrison, 2011), parents' role and environment (Fathurrohman, 2017), as well the school readiness (Brooks, Elspeth, \& Murray, 2016) are also significant in building the students' readiness to learn. Mardati et al. (2019) stated that the teacher's values and leadership become the external factors influencing students' readiness. Therefore, the higher the teacher's leadership and values, the higher the students' readiness is. It includes motivation, development, and attention.

The learning process is aimed to provide new experiences for the students. Hence, the experience will improve their behavior, quantitatively, and qualitatively, in the learning process (Widyaningtyas, 2003). Learning readiness is not only influenced by age, but also by family, school, and society. Children's experience at school and the educators' influences one another. Students are said to be ready when they are physically, mentally, and emotionally prepared to learn (Shrestha, 2019).

In general, learning readiness is an individual's capability to take the benefit of his experience. Readiness in this study refers to the readiness of a learner to follow the learning process. Learning readiness consists of attention, motivation, and readiness development (Nasution, 2010: 179). In addition, Wynn (in Jena, 2016) proposed that the physical, social, and emotional development influence the acquirement of skills during the learning process. Similar to this idea, Nurhasah and Sobandi (2016) stated that attention is one of the internal factors that influence students' learning outcomes.

\section{Factors Influencing Students' Learning Readiness}

Several factors, both external and internal influence learning readiness. Darsono (2000) categorized the factors into two: physical and psychological condition. A compromising physical circumstance can affect other factors required in the learning process. Similarly, a learner's psychological condition can also affect him in following the learning activities. Different from Darsono, 
Djamaroh added that learning readiness is also influenced by material readiness, such as the availability of the materials. The better is the support, the higher the learning readiness (Djamaroh, 2011). Soemanto (2012) mentioned that learning readiness is determined by two factors: motivation and physiological aspects. Physiological growth and components refer to the growth of an individual's physiological component, such as senses and intellectual capacity. Motivation includes the necessity, interest, as well as intentions to maintain as well as develop the capacity

\section{Principles of Learning Readiness}

A behavioristic psychologist, Thorndike, proposed the principles of learning readiness. In theory, he mentioned that one of the essential principles in learning is readiness. He stated that the more ready an organism receiving changes in behavior, the more strengthened the satisfaction produced by the behavior in an individual. Therefore, if an individual is prepared to receive or to do something, he will get better learning outcomes and satisfaction (Rahyubi, 2012: 35).

Thorndike explained that the first principle of connectionism theory is that learning aims to establish an association between the senses and the tendency to act. The readiness principle covers three areas. First, if a person tends to act and proceeds with the action, he will feel satisfied that he does not take another action. Second, if a person tends to act but does not continue to take any action, he will not get the satisfaction. As a result, he will take another action to decrease the dissatisfaction. Third, if a person does not have the tendency to act, but he has the urge to take any action, he will feel less satisfied and thus take another action to lessen the dissatisfaction.

\section{Learning readiness and students' academic achievement}

Furthermore, learning readiness can improve students' academic achievement. Shresta (2019) proved that it has a positive correlation with academic performance, with the result $\mathrm{r}=.698, \mathrm{p}<0.01)$. Besides, it has a high correlation with the entire dimension of learning. Another study revealed that learning readiness is correlated with learning independence. Students gaining motivation or encouragement will be ready and capable of taking the opportunity in the learning process. Motivation will also increase students' interest and confidence (Bruin, 2007). Besides, strong motivation encourages students to learn more diligently, allowing them to achieve better.
Motivation can help increase students' eagerness in the learning process at school.

\section{Research Methods}

\section{Research Design}

The research belongs to a descriptive quantitative type. It aims to describe a condition objectively. It also uses a quantitative approach since it is an empirical study to collect, analyze, and present the data. In the present study, the data are the learning readiness in the implementation of a five-day school program. The data is displayed numerically. The research is conducted through a survey using a cross-sectional design.

\section{Participants}

The samples were taken using a non-probability method with sampling judgmental type by selecting the subjects based on the specific characteristics set by the researcher. The samples were from SMA N 5 Yogyakarta and SMA N 8 Yogyakarta, with the number of 145 students. They are from two classes of grade X MIPA of both schools (72 from SMA N 5 and 73 from SMA N 8). Based on the data, 56 of them are male and 89 female. The variables of the research are learning readiness, where the independent variable is the implementation of a five-day school program. The instrument used in the research is a questionnaire, by which the SPSS 16.0 program processed the data.

\section{Technique and instrument for collecting the data}

The data were gathered through a questionnaire. The instrument is a questionnaire about the students' learning readiness, which was filled online through Google form. The items were developed from the relevant theories explained in the previous section. Before conducting the empiric test, the draft of the questionnaire was consulted with two experts. After they were approved, the validity test was conducted empirically. Based on the empiric analysis, 29 of 30 items were approved as valid. The criteria for the testing refer to the formulation of $\mathrm{df}=\mathrm{n}$ with a significant level of $5 \%(\mathrm{r}$ table $=0,162)$. The result is stated as valid if $r$ count $>r$ table. If it is the otherwise, the item is invalid. 
Table 1. Instrument Validity

\begin{tabular}{|c|c|c|c|}
\hline Item Number & r Count & r Table & Explanation \\
\hline 1 & 0,494 & 0,162 & Valid \\
\hline 2 & 0,178 & 0,162 & Valid \\
\hline 3 & 0,574 & 0,162 & Valid \\
\hline 4 & 0,419 & 0,162 & Valid \\
\hline 5 & 0,171 & 0,162 & Valid \\
\hline 6 & 0,423 & 0,162 & Valid \\
\hline 7 & 0,456 & 0,162 & Valid \\
\hline 8 & 0,451 & 0,162 & Valid \\
\hline 9 & 0,431 & 0,162 & Valid \\
\hline 10 & 0,305 & 0,162 & Valid \\
\hline 11 & 0,398 & 0,162 & Valid \\
\hline 12 & 0,353 & 0,162 & Valid \\
\hline 13 & 0,177 & 0,162 & Valid \\
\hline 14 & 0,580 & 0,162 & Valid \\
\hline 15 & 0,581 & 0,162 & Valid \\
\hline 16 & 0,632 & 0,162 & Valid \\
\hline 17 & 0,475 & 0,162 & Valid \\
\hline 18 & 0,491 & 0,162 & Valid \\
\hline 19 & 0,598 & 0,162 & Valid \\
\hline 20 & 0,275 & 0,162 & Valid \\
\hline 21 & 0,511 & 0,162 & Valid \\
\hline 22 & 0,630 & 0,162 & Valid \\
\hline 23 & 0,593 & 0,162 & Valid \\
\hline 24 & 0,082 & 0,162 & Invalid \\
\hline 25 & 0,598 & 0,162 & Valid \\
\hline 26 & 0,528 & 0,162 & Valid \\
\hline 27 & 0,342 & 0,162 & Valid \\
\hline 28 & 0,479 & 0,162 & Valid \\
\hline 29 & 0,679 & 0,162 & Valid \\
\hline 30 & 0,430 & 0,162 & Valid \\
\hline
\end{tabular}

This normality test uses Kolmogorov Smirnov by comparing the distribution of data that be tested for normality with the standard normal distribution. Significance above 0,05 means that there is no significant difference between the data to be tested and the standard normal data.
Table 2. Sample Kolmogorov-Smirnov test

\begin{tabular}{|c|c|c|}
\hline \multicolumn{2}{|c|}{$\mathrm{N}$} & VAR00001 \\
\hline \multirow{2}{*}{$\begin{array}{c}\text { Normal Parameters } \\
\text { a }\end{array}$} & Mean & 145 \\
\cline { 2 - 3 } & Std. Deviation & 75.9655 \\
\hline \multirow{3}{*}{$\begin{array}{c}\text { Most Extreme } \\
\text { Differences }\end{array}$} & Absolute & .093 \\
\cline { 2 - 3 } & Positive & .043 \\
\cline { 2 - 3 } & Negative & -.093 \\
\hline \multicolumn{2}{|c|}{ Kolmogorov-Smirnov Z } & 1.115 \\
\hline \multicolumn{2}{|c|}{ Asymp. Sig. (2-tailed) } & .166 \\
\hline
\end{tabular}

Based on the results of the normality test with the Kolmogorov Smirrnov test above shows the output of the Kolmogorov Smirnov $Z$ is 1,115 and the Asymp Sig. amounted to 0,166 greater than 0,05 . It can be concluded that the data is normally distributed.

\section{Findings}

\section{Measurement results}

The reliability test was conducted using Cronbach's Alpha type: the value of Cronbach's Alpha $>0.60$, the questionnaire is considered as reliable or consistent. If the Cronbach's Alpha value shows less than 0.60, the questionnaire is considered as not reliable or inconsistent. Through SPSS 16.0, it is known that the Cronbach's Alpha value for the instrument of students' learning readiness was 30 . The reliability test was 0.782 . Therefore, the questionnaire is reliable, meaning that the consistency degree of the instrument is medium reliable.

Based on the reliability test, the Cronbach's Alpha scored 0.782 . Based on the validity and reliability tests to 30 items of the questionnaire, 1 items were stated as invalid. Descriptive analiysis is an analysis conducted to assess the characteristics of a data. Data characteristics include: range, minimum, maximum, mean and standard deviation. Descriptive statistics are known in the table 3.

Table 3. Descriptive Statistics

\begin{tabular}{ccccccc}
\hline & N & Range & Minimum & Maximum & Mean & $\begin{array}{c}\text { Std. } \\
\text { Deviation }\end{array}$ \\
\hline $\begin{array}{c}\text { Ready to } \\
\text { Learn }\end{array}$ & 145 & 40 & 54 & 94 & 75.97 & 7.882 \\
\hline $\begin{array}{c}\text { Valid N } \\
\text { (listwise) }\end{array}$ & 145 & & & & & \\
\hline
\end{tabular}

Based on descriptive statistical results obtained a mean of 75.97 and a standard deviation of 7.882. Then the data is categorized based on the scores obtained aiming to find out the position of each individual in the very high, high, medium, low and low categories. The score categorization is based on the trend interval formula as table 4 . 
Table 4. Score Kategorization

\begin{tabular}{ccccccc}
\hline Interval Kecenderungan & Skor & Kategori & Frequency & Percent & $\begin{array}{c}\text { Valid } \\
\text { Percent }\end{array}$ & $\begin{array}{c}\text { Cumulative } \\
\text { Percent }\end{array}$ \\
\hline $\mathrm{X}>\mathrm{M}+1.5 \mathrm{SD}$ & $89>$ & Extremely High & 13 & 9.0 & 9.0 & 9.0 \\
$\mathrm{M}+0.5 \mathrm{SD}<\mathrm{X}<\mathrm{M}+1.5 \mathrm{SD}$ & $80-88$ & High & 24 & 16.6 & 16.6 & 25.5 \\
$\mathrm{M}-0.5 \mathrm{SD}<\mathrm{X}<\mathrm{M}+0.5 \mathrm{SD}$ & $72-79$ & Medium & 60 & 41.4 & 41.4 & 66.9 \\
$\mathrm{M}-0.5 \mathrm{SD}<\mathrm{X}<\mathrm{M}-0.5 \mathrm{SD}$ & $65-71$ & Less & 41 & 28.3 & 28.3 & 95.2 \\
$\mathrm{X}<\mathrm{M}-1.5 \mathrm{SD}$ & $64<$ & Low & 7 & 4.8 & 4.8 & 100.0 \\
\hline
\end{tabular}

\section{Data Analysis}

As a whole, it is found that no students have extremely high level of readiness 13 student (9\%), 24 students high $(16,6 \%), 60$ medium $(41,4 \%), 41$ less $(28,3 \%)$, and low 7 student $(4,8 \%)$. The description category of students' learning readiness can be seen in figure 1 .

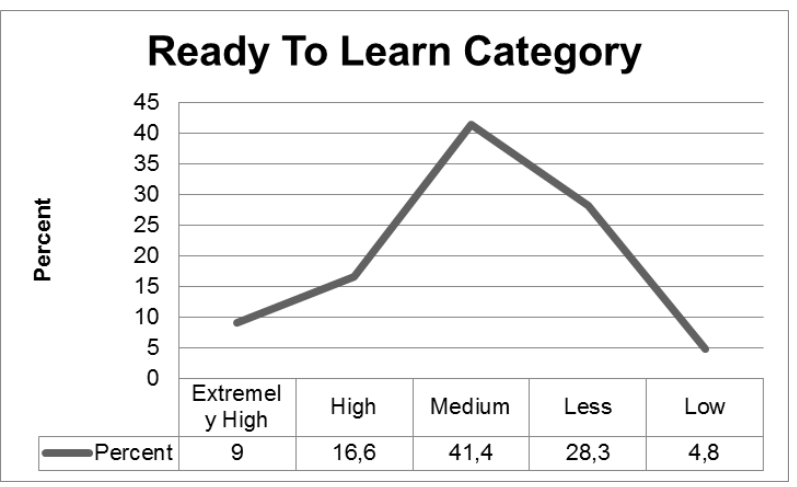

Figure 1. Students' Learning Readiness

Meanwhile, in terms of attention, motivation, and development, the students are found to be at various levels.

\section{a. Attention for learning}

Based on the data, are in extremely high level of readiness 9 student (6\%), 46 in high category (32\%), 47 in medium category (32\%), 34 in rather low category $(23 \%)$, and 9 student is in the low category (6\%). The percentage can be seen in figure 2

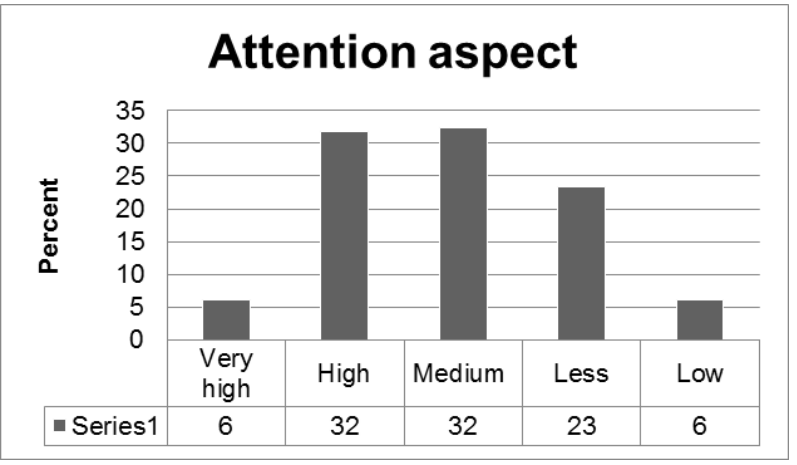

Figure 2. Attention Aspect c. Motivation Aspect

The analysis on students' learning motivation shows 4 students in extremely high category (3\%), 51 in high category (35\%), 55 in medium category (38\%), 21 in rather low category $(14 \%)$, and 14 in low category $(10 \%)$. The percentage of students' learning motivation is presented in figure 3 .

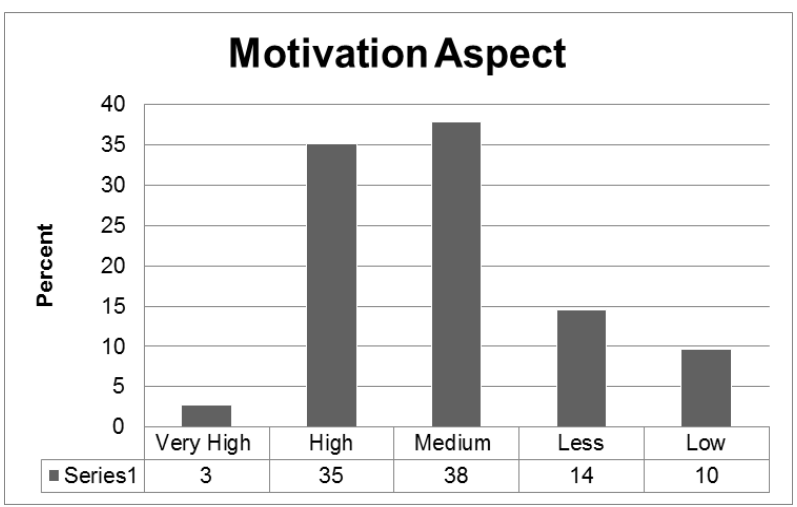

Figure 3. Motivation Aspect

b. Readiness Development

In terms of readiness development, 4 students are in extremely high category (3\%), 55 in high category $(38 \%)$, 48 in medium category (33\%), 14 in rather low category $(10 \%)$, and 14 in low category $(10 \%)$. The percentage is shown in the following figure 4.

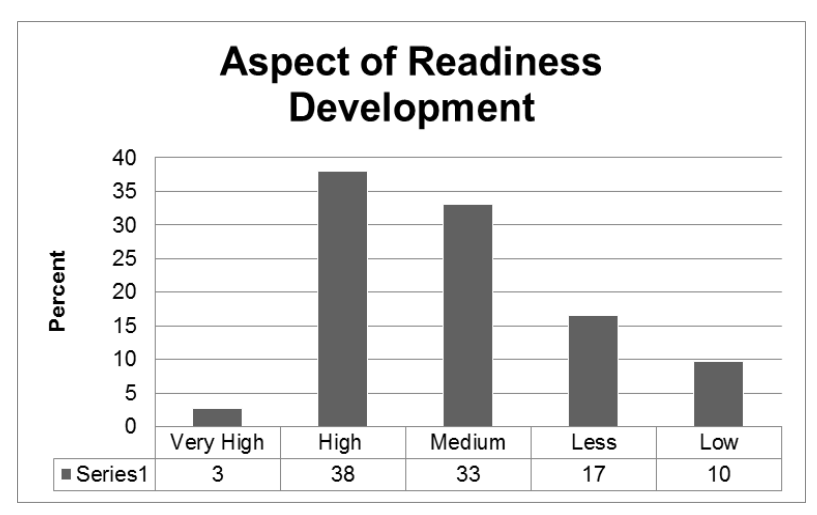

Figure 4. Aspect of Readiness Development

The analysis found that readniess development aspect is 
at the highest level, among other aspects, while attention is at the lowest.

\section{Discussion}

There are three main findings of the research. Readiness development aspect is in the highest position (3\% students in extremely high category and $38 \%$ in the high category), while attention is in the lowest (none percent of the students are in the extremely high category, $32 \%$ in high category, $23 \%$ in medium, and $10 \%$ in rather low and low category). Motivation aspect is in between and the distribution is the most even compared to two other aspects.

Students still have time management, follow learning in class and do the assignments given by the teacher. This finding can be strengthened from the result of student's learning motivation which has an even distribution compared to the other two aspects. On form of student responsibility in school is to do the task well, and can apply learning independence so learning is more meaningfull in life. Therefore there is encouragement in students who can do the task well and are supported by intrinsic motivation which is the main necessity of the students to support their success (Rudy, 2011). Learning motivation is one of the intrinsic elements in students' learning readiness at school. Motivation is part of psychology and of an individual's behavior in investing his time, in completing the task, and in thinking (Bakar, 2014). Aritonang (2008: 14) stated that learning motivation is influenced by several factors, such as students' learning capability, students' condition, and the dynamic elements in learning. Highly motivated students tend to come early to school. Motivation directs the students in the learning process, allowing them to achieve the objective of the learning. It takes the form of students accomplishing the tasks, students gaining maximum learning outcome, and students getting meaningful learning, as well as being independent (Riduwan, 2006). Autonomous learning readiness will lead the students to effective learning (Prabjandee, 2013). Independent learners will take the opportunity of independent learning by showing intrinsic motivation and interest, as well as positive dignity and confidence during the learning process (Bruin, 2007). Besides, professional educator's development can also increase students' achievement (Pendergast, 2015). In other words, learning readiness implies a certain level of thought and the excitement to do something (Hayden, 2008). The motivation can also come from the teachers' soft skills in conducting the learning process. Suyatno et.al (2019a; $2019 b$ ) stated that teachers who teach using particular values, such as empathy, happiness, and enthusiasm will give positive impact on students' learning motivation.

The second finding relates to the students' attention, which is on the lowest category. There are three indicators of attention in the present study: concentration, responsiveness, and interest in the learning materials. It shows that the length of the learning hour as the result of five-day school program in SMA N 5 Yogyakarta has lessened the students' attention. Yungwei (2016) revealed that students' attention is influenced by the learning process and the teacher in the classroom. Students with high level of readiness tend to respond better, allowing them to build their confidence. Self-confidence is closely related to learning readiness (Eslaminejad, 2016). It influences the cognitive, social, and emotional aspects of the students, such as in responding to the teacher's question, in raising questions to the teacher, and in maintaining their concentration (Janus, 2007). Suyatno et.al (2019c) also stated that a teacher who also becomes the role model for the students will increase their interest in following the learning materials, allowing them to give more attention. Therefore, low level of attention found in the present study may be caused by the longer period of learning and the teacher's failure in increasing the students' interest in learning.

The third finding is the learning motivation. The indicators of this aspect include students' seriousness in following the learning process in the classroom. All categories have even distribution in the highest $(3 \%)$ and in the lowest category $(10 \%)$. As many as 51 students $(35 \%)$ are in high category. From the questionnaire, it is revealed that students can relate the learning materials to their daily life $(46.9 \%)$. It is the process where information or experience gained by an individual enters his mental structure. The process is called assimilation. In the theory of learning, it is mentioned that an individual's mental development is influenced by several factors, such as maturity, physical experience, mathematical-logical experience, social transmission (social interaction), and balance (Piaget, 1974). In the theory, students are interested in group work, which becomes their information and learning experience, as well as their academic learning at school (Song, 2015).

The improvement of students' learning readiness that leads to their motivation and confidence (Dangol \& Milan, 2019; Kearney \& Garfield, 2019) can increase their learning outcome. Conversely, less readiness can decrease the success of classroom activities. In determining the learning objectives, teachers need to pay attention to the development level of students' learning readiness (Weistein \& Wu, 2009; Xu et al., 2017). Brigman and Linda (2003) mentioned that the materials and strategies employed in the classroom could also affect the learning readiness of the students. Learning readiness can provide students with the skills necessary for their future (Grigoyeva, 2019).

The questionnaire, with 29 items of questions, revealed the fact that student has good readiness in learning (61\%). However, from the five-day school program, it is found 
that students faced several problems. Many of the students $(57.9 \%)$ stated that they often have problems in concentrating, and $52.4 \%$ often lose concentration due to exhaustion, and $44.9 \%$ rarely arrange their own learning schedule at home, and $48.3 \%$ often find difficulties in completing the tasks on time due to tiredness.

The findings provide evidence for the research conducted by Loima et al. (2016), in that highly motivated students tend to accomplish the task better. Similar to the study, the students with readiness development are in high category (38\%) and motivation in high category $(35 \%)$. However, many students $(32 \%)$ are in medium and high category in the aspect of attention. Readiness development takes the form of students' ability in accomplishing the task as required. It is evident in the full activities done by the students at school. Nevertheless, lack of attention may decrease the success of learning. It is similar to previous studies, concluding that low level of attention will lessen the learning concentration and critical thinking. Nurhasanah (2016) found that students' attention to the learning process is less optimal, leading to the decrease of learning interest. Wang and Adesope (in Nurhasanah, 2016), revealed three important aspects in an individual's knowledge: attention, goals, and level of learning.

As a part of the strategies to prevent the negative impact of five-day school policy, the school can take several efforts. For example, the school needs to create a compromising school climate, establish professional management, and improve the teachers' creativity in the teaching process. The research by Dronkers and Robert (2008), Brunello and Rocco (2008), as well as Iqbal (2012) found that schools with a good climate can increase the students' learning readiness. Besides, the supports of the professional school management and academic services create a comfortable learning environment. Meanwhile, Fidana and Oztürk (2015), Urquiola (2016), and Amurdawati et al. (2020) mentioned that the teachers' creativity influences students' learning readiness in conducting the teaching process. The more creative is the teacher, the higher the students' readiness.

\section{Conclusions}

The policy established for education needs to be accumulated with the students' learning readiness in order to maintain their concentration. Besides, it will help the students learn better, come to school on time, finish the task accordingly, and gain the benefits of the learning experience that will be useful for themselves and the social environment. Therefore, the three aspects that consist of attention, motivation, and readiness development are closely related to the success of a five-day school implementation. Students' readiness will decrease if they lack concentration, cannot manage the independent learning schedule at home, and cannot finish the tasks properly due to exhaustion.

The students attending the public senior high schools in Yogyakarta are mostly from an educated family and upper-middle economy class. Besides, their academic skills are above average, and they are supported with adequate school facilities and infrastructures to implement a five-day school program. Therefore, the samples of the research cannot represent the schools in Yogyakarta in general. Students in the villages are from various backgrounds in terms of financial condition and academic skills. Besides, they are not supported by sufficient facilities to implement the program. Thus, another research is necessary to measure the students' learning readiness in facing a five-day school policy using a broader scope of samples, involving schools with different demographic conditions, both private and public schools, either in the cities or the villages. This way, it is expected that the result can be a useful reference for the government in evaluating a five-day program. 


\section{Appendix 1. Research Instrument}

\begin{tabular}{|c|c|}
\hline No. & Statement \\
\hline \multirow[t]{2}{*}{1} & I concentrate when the teacher explains the subject matter in class. \\
\hline & My concentration decreased during the last lesson. \\
\hline 2 & I have a way to maintain concentration while the lesson is in progress. \\
\hline 3 & I do not play cellphone when in class so as not to interfere with the concentration of learning. \\
\hline 4 & I answer the questions given by the teacher. \\
\hline 5 & I have trouble concentrating due to my busy study hours. \\
\hline 6 & I was confused to answer questions from the teacher. \\
\hline 7 & If there are materials that I don't understand, I immediately ask the teacher. \\
\hline 8 & I didn't ask the teacher even though I didn't understand the material. \\
\hline 9 & I have trouble concentrating studying at home because I'm tired. \\
\hline 10 & I prepare stationery and books at night so I don't come late to school. \\
\hline 11 & I came to school on time. \\
\hline 12 & I didn't let go during the lesson. \\
\hline 13 & I study hard to get good learning results \\
\hline 14 & In the evening I read the lesson material for tomorrow. \\
\hline 15 & I learned not to be remedial \\
\hline 16 & I went into material from other sources besides the mandatory student handbook. \\
\hline 17 & I have a study schedule at home independently. \\
\hline 18 & I actively record the materials explained by the teacher in class \\
\hline 19 & I use Saturdays to do assignments and study at home. \\
\hline 20 & I can relate the material that I learned in school to my daily life. \\
\hline 21 & I do the job given by the teacher as well as possible. \\
\hline 22. & I spend time at home doing homework. \\
\hline 23. & I can finish the homework given by the teacher well. \\
\hline 24 & For me doing homework can make me better understand the subject matter. \\
\hline 25 & When there are group assignments, I do not work on the assignments \\
\hline 26. & Not all lessons can be applied in my daily life. \\
\hline 27. & I find it hard to do my work on time. \\
\hline 28. & I find it hard to do my work at night because I'm tired. \\
\hline
\end{tabular}

Note: The original questionnaire was written in Indonesian. For the purposes of article publication, the questionnaire was translated in English

\section{REFERENCES}

[1] Amurdawati,, G., Suyatno, Pambudi,, D.I., Wantini, \& Hendrik, M. (2020). Analysis on Students' Learning Readiness in Junior High Schools of Pangkalpinang, Bangka Belitung. Universal Journal of Educational Research, 8 (8).

[2] Anifah, H. L., \& Nila, K. (2016). Impact Analysis of A five-day School Program (PS5H) on Students' Academic Stress towards the Effectiveness of Mathematics Learning in SMA Negeri 1 Purworejo. Ekuivalen. 24. 3, 46-52.

[3] Bakar, R. (2014). The effect of learning motivation on students productive competencies in vocational high school, West Sumatra. International Journal of Asian Social Science, 4(6), 2226-5139.

[4] Brooks, Elspeth \& Murray, J. (2016). Ready, steady, learn: school readiness and children's voices in English early childhood settings. International Journal of Primary, Elementary and Early Years Education. Education. 3-13, 2016

[5] Brunello, G., \& Rocco, L. (2008). Educational standards in private and public schools. The Economic Journal, 118(533), $1866-1887$
[6] Dangol, R. \& Milan, S. (2019). Learning Readiness and Educational Achievement among School Students. The International Journal of Indian Psychology. 7. 467-476. $10.25215 / 0702.056$

[7] Darsono (2000). Belajar dan Pembelajaran [Study and Learning]. Semarang: IKIP Semarang Press

[8] De Bruin, K. (2007). The relationship between personality traits and self-directed learning readiness in higher education students. South African Journal of Higher Education, 21(2), 228-240. https://doi.org/10.4314/sajhe.v21i2.25632

[9] Dishion, T. J., \& Tipsord, J. M. (2011). Peer contagion in child and adolescent social and emotional development. Annual Review of Psychology, 62, 189-214. DOI:10.1146/annurev.psych.093008. 100412.

[10] Djamarah, S. B. (2011). Psikologi Belajar [Psychology of Learning]. Jakarta: Rineka Cipta.

[11] Dronkers, J., \& Robert, P. (2008). Differences in the scholastic achievement of public, private government-dependent, and private independent schools: A cross-national analysis. Educational Policy, 22(4), 541-577.

[12] Fathurrohman, M.T. (2017). Influence of Parents Attention Against Student Achievement Class V. Jurnal Pendidikan Guru Sekolah Dasar. 10 (6).

[13] Fidan, T., \& Oztürk, I. (2015). The relationship of the 
creativity of public and private school teachers to their intrinsic motivation and the school climate for innovation. Procedia-Social and Behavioral Sciences, 195, 905-914.

[14] Grace, D. J., \& Brandt, M. E. (2006). Ready for success in kindergarten: A comparative analysis of teacher, parent, and administrator beliefs in Hawaii. Journal of Early Childhood Research, 4(3), 223-258.

[15] Grigoryeva, M. (2019). Students' Readiness for Changes as A Predictor of Social Activity. 43-48. 10.15405/epsbs.2019.02.02.6.

[16] Hayden, K. (2008). Learning readiness for your students. Retrieved from http://www.brighthub.com/members/khayden5.asp.

[17] Horwitz, E. K. (1985). Using student beliefs about language learning and teaching in the foreign language methods course. Foreign Language Annals, 18, 333e 340.

[18] Ikhwandhia, M. (2016). Abstract Collection of Research Results of Universitas Negeri Yogyakarta. Yogyakarta: LPPM Universitas Negeri Yogyakarta.

[19] Iqbal, M. (2012). Public versus private secondary schools: A qualitative comparison. Journal of Research and Reflections in Education, 6(1), 40-49.

[20] Janus, M. (2007). "The Early Development Instrument: A Tool for Monitoring Children's Development and Readiness for School." In M. E. Young (Ed.), Early child development from measurement to action: A priority for growth and equity, pp. 141-155.

[21] Jena, R.K. (2016). Investigating the interrelation between attitudes, learning readiness, and learning styles under virtual learning environment: a study among Indian students

[22] Karabük, A. P. D. Ö. K. (2015). The influence of learner readiness on student satisfaction and academic achievement in an online program at higher education. Turkish Online Journal of Educational Technology, 14(1), 133-142.

[23] Kearney, W. S., \& Garfield, T. (2019). Student Readiness to Learn and Teacher Effectiveness: Two Key Factors in Middle Grades Mathematics Achievement. RMLE Online, 42(5), 1-12.

[24] Kemendikbud (2017). Peraturan Kementrian Pendidikan dan Kebudayaan No 23 Tahn 2017 tentang Hari Sekolah [Ministry of Education and Culture Regulation No. 23 of 2017 concerning School Days].

[25] Lambert, L. (2003). Leadership redefined: An evocative context for teacher leadership. School Leadership \& Management, 23(4), 421-430.

[26] Lim, D.H. (2004). Cross-cultural differences in online learning motivation. Educational Media International, 41(2): $163-173$.

[27] Main, K., \& Pendergast, D. (2015). Core Vietures of Effective Continuing Profesional Development for The Middle Years: A Tool for Reffelction. Research in Middle-Level Education Online, 38 (10)

[28] Mardati, A., Suyatno, \& Pambudi, D.I. (2019). Influence of Teacher Leadership and Teacher Values on Students Learning Readiness at Junior High School in Pangkalpinang City. International Journal of Scientific \& Technology
Research Volume 8(10), p. 3411-3416.

[29] Murraya, E. \& Harrison, L.J. (2011). The influence of being ready to learn on children's early school literacy and numeracy achievement. Educational Psychology. Vol.31. No. 5. P. 529-545.

[30] Ningrum, P.P.D. (2019). Pengaruh Pembelajaran Sekolah Lima Hari, Kemandirian Belajar terhadap Prestasi Belajar Siswa XII Pemasaran SMK Negeri 1 Surakarta Ajaran 2018/2019 [The Effect of Five Day School Learning, Learning Independence on Student Achievement in Marketing XII of SMK Negeri 1 Surakarta 2018/2019]. Jurnal Pendidikan Bisnis dan Ekonomi, 4(2), 1-16. https://doi.org/10.1093/qjmed/hcy132/5040729

[31] Nurhasanah, S. A. \& Sobandi. (2016). Minat Belajarsebaga Determinanhasil Belajar Siswa. (Learning Interest as Determinant Student Learning Outcomes). Jurnal pendidikan manajemen perkantoran. 1(1), p. 128-135.

[32] Peraturan Presiden No. 87 tahun 2017 tentang Penguatan Pendidikan Karakter [Presidential Regulation No. 87 of 2017 concerning Strengthening Character Education].

[33] Piaget, J. \& Inhelder, B. (1974). The Child's Construction of Quantities. London: Routledge \& Kegan Paul

[34] Prabjandee, D., \& Inthachot, M. (2013). Self-Directed Learning Readiness of College Students in Thailand. Journal of Educational Research and Innovation, 2(1), 1-11.

[35] Rahmawati, A. \& Tairas, M.M.W. N. (2018). Children's School Readiness Based on Teachers' and Parents' Perceptions. International Journal of Pedagogy and Teacher Education, 2(1), 9-20.

[36] Rahyubi, H. (2012). Teori-teori Belajar dan Aplikasi Pembelajaran Mototrik [Learning Theories and Mototric Learning Applications]. Bandung: Nusa Media.

[37] Saeid, N., \& Eslaminejad, T. (2016). Relationship between student's self directed-learning readiness and academic self-efficacy and achievement motivation in students. International education studies. 10(1), 225-232.

[38] Schober, A., \& Keller, L. (2012). Impact factors for learner motivation in Blended Learning environments. iJET Volume 7, Number 2012, Feb 17, 2012.

[39] Shrestha, M. (2019). Learning Readiness and Educational Achievement among School Students. Indian Psychology, 7(2), 468. https://doi.org/10.25215/0702.056

[40] Soemanto, W. (2012). Psikologi Pendidikan [Educational Psychology]. Jakarta: Rineka Cipta.

[41] Song, J., Bong, M., Lee, K., \& Kim, S.-i (2015) Longitudinal investigation into the role of perceived social support in adolescents' academic motivation and achievement. Journal of Educational Psychology, 107(3), 821-841. DOI:10.1037/edu0000016.

[42] Suharno, Budiharjanto, Handayani, N.M. \& Sutanti (2018). Evaluation Of A five-day School Program Implementation Using The Model Of Contex, Input, Process, And Product. Jurnal Pendidikan Teknologi dan Kejuruan, Vol. 24, No. 1

[43] Suyatno, Jumintono, Pambudi, D. I., Mardati, A., \& Wantini. (2019a). Strategy of values education in Indonesia education system. International Journal of Instruction, 12(1), 607-624. 
https://doi.org/10.29333/iji.2019.12139a

[44] Suyatno, Pambudi, D.I., Mardati, A., Wantini, Nuraini, E., \& Yoyo. (2019b). The Education Values of Indonesian Teachers: Origin, Importance, and Its Impact on Their Teaching. International Journal of Instruction, 12(3), 633-650. https://doi.org/10.29333/iji.2019.12338a

[45] Suyatno, Wantini, Baidi, \& Amurdawati, G. (2019c). The Influence of Values and Achievement Motivation on Teacher Professionalism at Muhammadiyah 2 High School Yogyakarta, Indonesia. The Journal of Pedagogika / Pedagogy t. 133, Nr. 1, p. 105-127.

[46] Triyono, Sari, P.N. \& Lestari, S. (2018). Academic Civitas Perception to 5 Days School Implementation for Senior High School and Equivalent. International Conference on Economics, Business, and Economic Education. Pages 1-11.

[47] Urquiola, M. (2016). Competition among schools: Traditional public and private schools. In Handbook of the Economics of Education (Vol. 5, pp. 209-237). Elsevier.

[48] Wang, Z., \& Adesope, O. (2016). Exploring the Effects of Seductive Details with The 4-Phase model of Interest. Learning and Motivation, 55, 65-77

[49] Weinstein, S. E., \& Wu, S. W. (2009). Readiness assessment tests versus frequent quizzes: Student preferences.
International Journal of Teaching and Learning in Higher Education, 21(2), 181-186.

[50] Widyaningtyas, A., Karmin, S., \& Radiyono, Y. (2013). Peran Lingkungan Belajar Dan Kesiapan Belajar Terhadap Prestasi Belajar Fisika Siswa Kelas X Sekolah Menengah Atas Negeri 1 Pati [The Role of Learning Environment and Learning Readiness on Physics Learning Achievement in Class X State Senior High School 1 Pati]. Jurnal Pendidikan Fisika, 1(1), 136-143.

[51] Wynn, L. (2002). School Readiness: Starting Your Child Off Right. Raleigh, NC: North Carolina Partnership for Children.

[52] Xu, T., Byker, E. J., \& Gonzales, M. R. (2017). Ready to learn: The impact of the Morning Blast physical activity intervention on elementary school students. Malaysian Journal of Movement, Health \& Exercise, 6(1).

[53] Yuan, H. B., Williams, B.A., Fang, J.B. \& Pang, D. (2012). Chinese Baccalaureate Nursing Students' Readiness For Self Directed Learning. Nurse Education Today.

[54] Yungwei, H. (2016). Middle School Students' flipped Learning Readiness In Foreign Language Classrooms: Exploring Its Relationship With Personal Characteristics And Individual Circumstances. Computers in Human Behavior. Vol. 59. P. 295-303. 